\title{
Urinary uric acid to creatinine ratio as a marker of perinatal asphyxia and its correlation with arterial blood gas values
}

\author{
Priya Sharma (D), Krishnaswami DeviMeenakshi \\ Department of Pediatrics, Government Kilpauk Medical College, Chennai, Tamil Nadu, India
}

\begin{abstract}
Objective: Perinatal asphyxia is a leading cause of neonatal morbidity and mortality in developing countries. Lack of facilities like arterial blood gas analysis in resource limited settings warrants cost effective methods to support the diagnosis of asphyxia. The study objectives were to evaluate the utility of urinary uric acid to creatinine ratio (UA/Cr ratio) as a marker of perinatal asphyxia and to ascertain its correlation with cord blood arterial blood gas values.

Methods: It was a prospective comparative study where cases and controls were of asphyxiated neonates and normal neonates respectively delivered in a tertiary care medical college hospital from April 2019 to September 2019. Urinary UA/Cr ratio and its correlation with Apgar score was determined. The ability to predict asphyxia was estimated by ROC curve and $\mathrm{p}<0.05$ was considered as statistically significant.

Results: Data from 38 asphyxiated and 38 normal neonates were analyzed. The mean urinary $\mathrm{UA} / \mathrm{Cr}$ ratio was higher in the asphyxiated babies. There was negative correlation between urinary UA/Cr ratio and $\mathrm{pH}, \mathrm{pO}_{2}$, Apgar scores and positive correlation with $\mathrm{pCO}_{2}$. The urinary UA/Cr ratio had excellent predictive validity for perinatal asphyxia determined by ROC curve. The urinary uric acid /creatinine ratio had sensitivity of $92.11 \%$ and specificity was $92.11 \%$.

Conclusion: Urinary uric acid to creatinine ratio correlated well with the cord blood arterial blood gas values and the Apgar scores. This study showed that there is a significant increase in the urinary $\mathrm{UA} / \mathrm{Cr}$ ratio in asphyxiated neonates and it can be used as a biochemical marker of perinatal asphyxia.
\end{abstract}

Keywords: Urinary uric acid to creatinine ratio, perinatal asphyxia.

\section{Introduction}

Perinatal asphyxia is a leading cause of neonatal morbidity and mortality in developing countries. Asphyxia accounts for $26 \%$ of the 3.2 million stillbirths and $23 \%$
Özet: Perinatal asfiksi belirteci olarak üriner ürik asidin kreatinine oranı ve arteryel kan gazı değerleri ile korelasyonu

Amaç: Perinatal asfiksi, gelişmekte olan ülkelerde neonatal morbidite ve mortalitenin önde gelen bir nedenidir. Sınırlı kaynağa sahip ortamlarda arteryel kan gazı analizi gibi olanakların bulunmaması, asfiksi tanısını desteklemek için uygun maliyetli yöntemleri gerektirmektedir. Çalışmamızın amaçları, perinatal asfiksi belirteci olarak üriner ürik asidin kreatinine oranının (UA/Cr oranı) kullanımını değerlendirmek ve kordon kanı arteryel kan gazı değerleri ile olan korelasyonunu araştırmaktı.

Yöntem: Çalışma, Nisan 2019 ile Eylül 2019 tarihleri arasında üçüncü basamak bir tıp fakültesi hastanesinde doğan ve sırasıyla asfiktik yenidoğanlar ile normal yenidoğanlardan oluşan olgu ve kontrolleri içeren prospektif bir karşılaştırmalı bir çalışmadır. Çalışmada üriner UA/Cr oranı ve Apgar skoruyla olan korelasyonu değerlendirildi. Asfiksiyi öngörme olasılığı ROC eğrisi ile tahmin edildi ve $\mathrm{p}<0.05$ değeri istatistiksel olarak anlaml kabul edildi.

Bulgular: Otuz sekiz asfiktik ve 38 normal yenidoğanın verileri analiz edildi. Ortalama üriner $\mathrm{UA} / \mathrm{Cr}$ oranı asfiktik bebeklerde daha yüksekti. Üriner $\mathrm{UA} / \mathrm{Cr}$ oranı ile $\mathrm{pH}, \mathrm{pO}_{2}$ ve Apgar skorları arasında negatif; $\mathrm{pCO}_{2}$ ile pozitif korelasyon vardı. Üriner UA/Cr oranı, ROC eğrisi ile belirlenen perinatal asfiksi için mükemmel kestirim geçerliliğine sahipti. Üriner ürik asit/kreatinin oranının hassasiyeti \%92.11, özgüllüğü ise \%92.11 idi.

Sonuç: Üriner ürik asidin kreatinine oranı, kordon kanı arteryel kan gazı değerleri ve Apgar skorları ile iyi şekilde koreledir. Calışmamız, asfiktik yenidoğanlardaki üriner UA/Cr oranında anlaml bir artış olduğunu ve perinatal asfiksinin biyokimyasal belirteci olarak kullanılabileceğini ortaya koymuştur.

Anahtar sözcükler: Üriner ürik asit/kreatinin oranı, perinatal asfiksi.

of 4 million neonatal deaths each year. ${ }^{[1]}$ About $2.8 \%$ and $5.6 \%$ of all live births have moderate and severe asphyxia, respectively. ${ }^{[2]}$ Hypoxia induced anaerobic glycolysis results in lactic acid production. Lack of

Correspondence: Krishnaswami DeviMeenakshi, MD. Department of Pediatrics, Government Kilpauk Medical College, Chennai, Tamil Nadu, India. e-mail: drdevi_1804@yahoo.in / Received: November 5, 2021; Accepted: December 2, 2021

How to cite this article: Sharma P, DeviMeenakshi K. Urinary uric acid to creatinine ratio as a marker of perinatal asphyxia and its correlation with arterial blood gas values. Perinatal Journal 2021;29(3):238-244. doi:10.2399/prn.21.0293010 
ATP causes accumulation of ADP and AMP which is then catabolized to adenosine, inosine and hypoxanthine. During reperfusion injury, hypoxanthine is oxidized to xanthine and uric acid in presence of xanthine oxidase that increases uric acid production which is excreted in urine. ${ }^{[3-7]}$ Extensive amounts of free oxygen radicals are produced in the reoxygenation period following which high levels of uric acid are produced and are excreted in the urine early in first day of life. An increased urinary uric acid to creatinine ratio (UA/Cr ratio) is a sign of lack of ATP and serves as a valuable indicator of tissue hypoxia.

Although arterial blood gas analysis provides supportive evidence for diagnosis of asphyxia, access to such facilities may be limited in developing countries. There is need for a cost effective and easily available method in order to make a diagnosis of asphyxia. This study was planned to ascertain the utility of urinary $\mathrm{UA} / \mathrm{Cr}$ ratio as a non-invasive biochemical marker for diagnosis of perinatal asphyxia. The study objectives were to assess the utility of urinary uric acid/creatinine ratio as a marker of perinatal asphyxia and to evaluate the correlation between urinary $\mathrm{UA} / \mathrm{Cr}$ ratio and umbilical cord arterial blood gas values in asphyxiated neonates.

\section{Methods}

The protocol of the study was approved by Institutional ethics committee (protocol ID 178/2019/meeting held in April 2019). Informed written consent from the parents of the neonates was taken before commencement of the study. It was a prospective comparative study where cases and controls comprised of asphyxiated neonates admitted in NICU and normal neonates respectively, delivered at a tertiary medical college hospital during the study period from April 2019 to September 2019.

All term neonates who had diagnosis of perinatal asphyxia based on any one of the following which included intrapartum signs of fetal distress (non-reassuring non-stress test or thick meconium staining of amniotic fluid) or Apgar score $\leq 6$ at 5 minutes or $\leq 3$ at more than 10 minutes or need for $>1$ minute of positive pressure ventilation or fetal bradycardia with heart rate $<60 /$ minute were included in the study. All neonates with congenital malformations, premature and intrauterine growth restricted neonates, neonates born to mothers on antiepileptic medications or administered magnesium sulphate or opioids, neonates of smoker mothers or mothers with alcohol/drug abuse were excluded.

All cases were term neonates who met the inclusion criteria while control group consisted of normal term neonates who were appropriate for gestational age. Detailed maternal history including risk factors like mode of delivery, birth events, Apgar score, mode of resuscitation, fetal gender, birth weight were recorded on the prestructured form. Gestational age was assessed by New Ballard score. Neurological assessment was done for all the neonates and asphyxiated neonates were monitored for convulsions, hypotonia and complications like acute kidney injury, persistent pulmonary hypertension etc. Urine samples were collected from the neonates within 6-24 hours of life using sterile urine collection bags. The umbilical cord arterial blood was collected by using the double clamp technique using pre-filled heparin syringes and was transported for analysis in ice box (Fig. 1).

Uric acid was analyzed with autoanalyzer by enzymatic colorimetric assay using uricase which forms quinoneimine dye that forms a red color. The intensity of red color was measured photometrically. Creatinine was estimated by assay principle on autoanalyzer by kinetic colorimetric assay using Jaffe method. The yelloworange color of creatinine picric acid complex was measured photometrically.

Sample size was calculated using mean urinary uric acid to creatinine ratio in perinatal asphyxia as 2.75 and in normal neonates as 1.78 , as per study by Patel et al ${ }^{[8]}$ The respective standard deviations used were 1.18 and 1.23 . The other parameters considered for sample size were $90 \%$ power of study and $5 \%$ alpha error. The following formula was used for calculation: $\mathrm{n}=(\mathrm{u}+\mathrm{v}) 2(\sigma 12+\sigma 02)$ $(\mu 1-\mu 0) 2$ (n- sample size; $\mu 1-\mu 0$ - difference between means 2.75 and $1.78 \sigma 1 ; \sigma 0$ - standard deviations 1.18 and 1.23 ; u- one sided percentage point of the normal distribution corresponding to $100 \%$ the power, the power $=90 \%, \mathrm{u}=1.28$; $\mathrm{v}$ - percentage point of normal distribution corresponding to two sided significance level e.g. if significance level $=5 \%, v=1.96)$. The required sample size in each group was calculated as 34 subjects and after addition of $10 \%$ for non-participation, the required sample size was 38 subjects in each group.

Descriptive analysis was carried out by mean and standard deviation for quantitative variables, frequency and proportion for categorical variables. Non normally distributed quantitative variables were summarized by medi- 


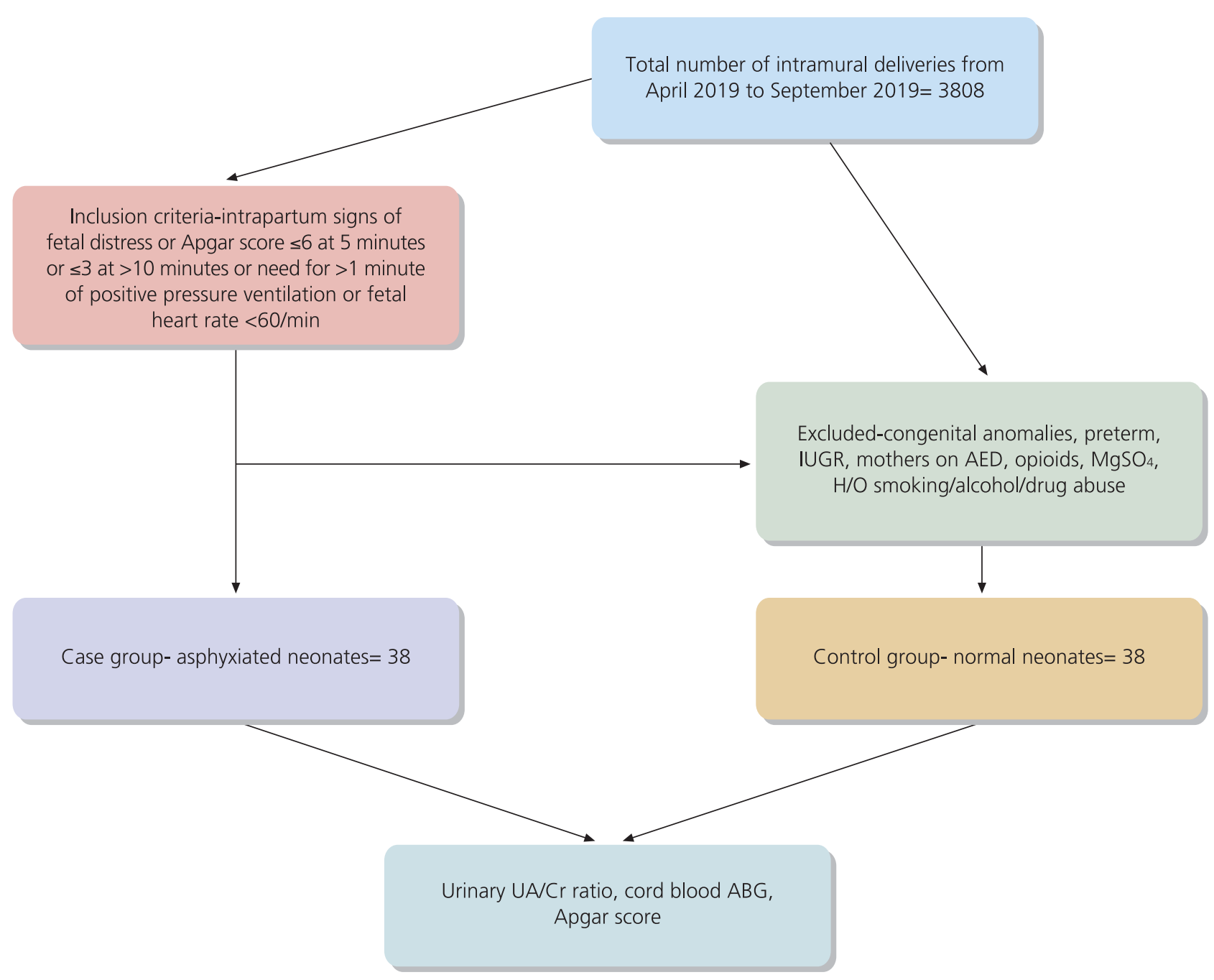

Fig. 1. Flow diagram for study enrolment.

an and interquartile range (IQR). The categorical variables were compared between the two groups by cross tabulation. Statistical significance of the differences in the proportion was assessed by chi square test or Fisher's exact test. Quantitative variables were compared by unpaired t-test. Mann-Whitney U test was applied to test the median 1-minute and 5-minute Apgar scores in both the groups. Ability of urinary UA/Cr ratio in predicting the perinatal asphyxia was assessed by receiver operating characteristic (ROC) curve analysis. Correlation between two quantitative variables was assessed by Pearson correlation coefsficient. A p-value $<0.05$ was considered as statistically significant. IBM SPSS statistical software version 21 (Armonk, NY, USA) was used for statistical analysis.

\section{Results}

A total of 76 neonates were included in the final analysis. Each group consisted of 38 neonates. It was observed that among the asphyxiated neonates there was a male preponderance with $20(52.63 \%)$ being males and $18(47.37 \%)$ being females. However, this was not statistically significant $(\mathrm{p}=0.818)$.

The mean maternal age \pm standard deviation was higher in the asphyxiated group $27.21 \pm 2.51$ as against $25.97 \pm 2.17$ in the normal group and this was statistically significant $(\mathrm{p}=0.024)$. The mean gestational age was similar in both groups $(38.32 \pm 0.61$ weeks in the cases and $38.11 \pm 0.5$ weeks in the controls, $\mathrm{p}=0.116$ ). 
Pregnancy induced hypertension (PIH) was the only risk factor in the normal group and it was present in all the babies. However, majority of the mothers $(81.58 \%)$ in the asphyxiated group did not have any risk factor. The risk factors seen in the asphyxiated group were anemia (2.63\%), gestational diabetes (2.63\%), PIH $(5.26 \%)$, premature rupture of membranes (PROM) (2.63\%), maternal fever $(2.63 \%)$ and cord prolapse $(2.63 \%)$.

About $50 \%$ of the babies in the asphyxiated group were delivered by LSCS and instrumental delivery [vacuum $(5.26 \%)$ \& forceps $(2.63 \%)$ ] was observed only in the asphyxiated group. In the normal group, $55.26 \%$ were delivered by normal vaginal delivery and only $44.74 \%$ were delivered by LSCS.

Comparing the indication for LSCS it was observed that fetal distress was present in $52.63 \%$ of neonates, prolonged labor in $15.79 \%$ and meconium stained liquor in $47.37 \%$ in the asphyxiated group and none of the babies in the normal group had these risk factors $(\mathrm{p}<0.001$ - fetal distress, $\mathrm{p}=0.087$ - prolonged labor, $\mathrm{p}<0.001$ - meconium stained liquor)

The median 1-minute Apgar scores (interquartile range IQR) were lower in the asphyxiated group [4(4.5)] as compared to control group [7(7.7)]. The median 5-minute Apgar scores (IQR) were lower in the asphyxiated group [7(6.7)] as compared to control group [8(8.8)]. The difference between the case and control groups was statistically significant $(\mathrm{p}<0.001)$.

Among the study population, 20 (52.6\%) participants had hypoxic ischemic encephalopathy (HIE) stage $1,14(36.8 \%)$ participants had HIE stage 2 and remaining $4(10.5 \%)$ participants had HIE stage 3 . The mean urinary $\mathrm{UA} / \mathrm{Cr}$ ratio was higher in the asphyxiated babies $(2.88 \pm 0.26)$ as compared to normal neonates $(1.56 \pm 0.15)$ and this was statistically significant $(\mathrm{p}<0.001)$ (Table 1).

There was a weak negative correlation between urinary $\mathrm{UA} / \mathrm{Cr}$ ratio and cord blood $\mathrm{pH}(\mathrm{r}=-0.244$, $\mathrm{p}=0.140$ ). There was a weak positive correlation between urinary $\mathrm{UA} / \mathrm{Cr}$ ratio and $\mathrm{PCO}_{2} \quad(\mathrm{r}=0.217$, $\mathrm{p}=0.191)$. There was a weak negative correlation between urinary $\mathrm{UA} / \mathrm{Cr}$ ratio and $\mathrm{PO}_{2}(\mathrm{r}=-0.134$, $\mathrm{p}=0.423$ ). There was a moderate negative correlation between urinary $\mathrm{UA} / \mathrm{Cr}$ ratio and 1-minute Apgar score $(\mathrm{r}=-0.710, \mathrm{p}<0.001)$. There was a moderate neg-
Table 1. Comparison of mean of urinary $\mathrm{UA} / \mathrm{Cr}$ ratio between the study groups $(n=76)$.

\begin{tabular}{|c|c|c|c|}
\hline \multirow[b]{2}{*}{ Parameter } & \multicolumn{2}{|c|}{$\begin{array}{c}\text { Birth asphyxia } \\
\text { (Mean } \pm \text { standard deviation) }\end{array}$} & \multirow[b]{2}{*}{ p-value } \\
\hline & Yes $(n=38)$ & No $(n=38)$ & \\
\hline UUA $/ \mathrm{Cr}$ ratio & $2.88 \pm 0.26$ & $1.56 \pm 0.15$ & $<0.001$ \\
\hline
\end{tabular}

ative correlation between urinary $\mathrm{UA} / \mathrm{Cr}$ ratio and 5minute APGAR score $(\mathrm{r}=-0.925, \mathrm{p}<0.001)$.

The urinary $\mathrm{UA} / \mathrm{Cr}$ ratio had excellent predictive validity in predicting perinatal asphyxia, as indicated by area under the curve (AUC) of 0.943 (95\% CI 0.887 to 0.999, p<0.001) (Fig. 2).

Among the asphyxiated neonates 35 (92.11\%) had a urinary $\mathrm{UA} / \mathrm{Cr}$ ratio $>2.71$ and in the normal group only $3(7.89 \%)$ had a ratio of $>2.71$. The difference in urinary $\mathrm{UA} / \mathrm{Cr}$ ratio between the neonates with and without perinatal asphyxia was statistically significant (p<0.001) (Table 2).

The urinary UA/Cr ratio had sensitivity of $92.11 \%$ in predicting perinatal asphyxia, specificity was $92.11 \%$, false positive rate was $7.89 \%$, false negative

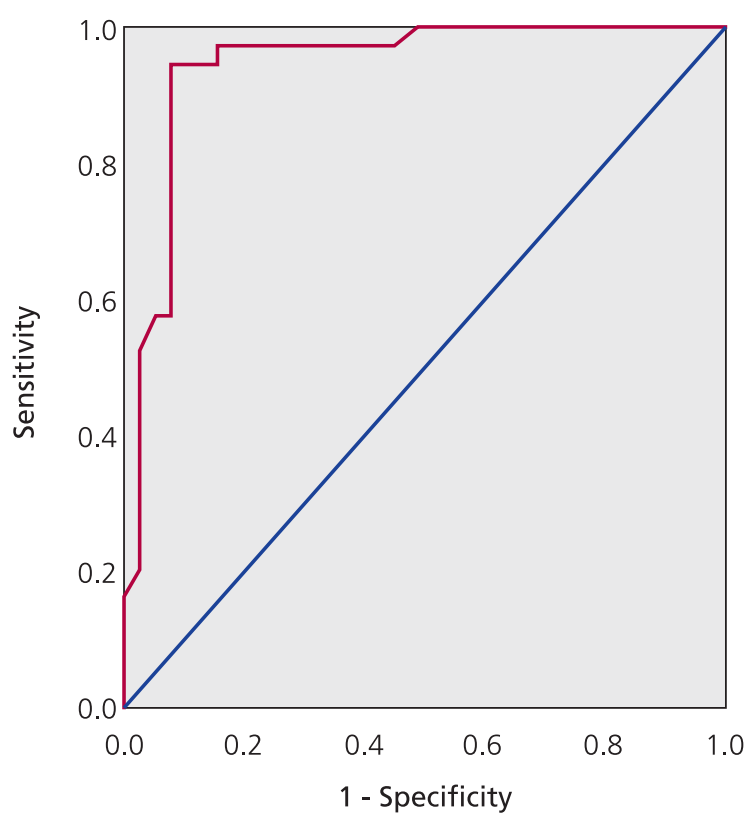

Diagonal segments are produced by ties.

Fig. 2. ROC curve. 
Table 2. Comparison of perinatal asphyxia with urinary UA/Cr ratio $(n=76)$.

\begin{tabular}{lcccc} 
& \multicolumn{2}{c}{ Perinatal asphyxia } & & \\
\cline { 2 - 3 } Urinary UA/Cr ratio & Yes $(\mathbf{n = 3 8})$ & No $(\mathbf{n = 3 8 )}$ & Chi-square & p-value \\
\hline 2.71 & $35(92.11 \%)$ & $3(7.89 \%)$ & 53.895 & $<0.001$ \\
$\leq 2.71$ & $3(7.89 \%)$ & $35(92.11 \%)$ & & \\
\hline
\end{tabular}

rate was $7.89 \%$, positive predictive value was $92.11 \%$, negative predictive value was $92.11 \%$ and the total diagnostic accuracy was $92.11 \%$ (95\% CI $83.60 \%$ to 97.05\%) (Table 3).

\section{Discussion}

Perinatal asphyxia is associated with impaired gas exchange during labor leading to fetal hypoxemia and hypercarbia which can be identified by acidosis measured in umbilical artery blood. ${ }^{[9]}$ Although there are no specific cut off values for defining asphyxia based purely on arterial blood gas values, it is generally agreed that an umbilical cord $\mathrm{pH}$ of $<7$ is suggestive of severe asphyxia. Hypoxia leads to cellular damage and loss of membrane integrity leading to cellular swelling. Ischemia causes further reduction in oxygen delivery. Once cardiac muscles are involved, hypoperfusion is worsened by declining cardiac output. ${ }^{[10]}$ Both hypoxia and ischemia cause damage to various organs like brain, kidney, heart, lungs etc. Since the ultimate goal is prevention of asphyxia induced morbidity, a plethora of markers have been studied to identify perinatal asphyxia such as electronic fetal cardiac monitoring, fetal scalp blood $\mathrm{pH}$, Apgar scores, cord blood $\mathrm{pH}$,
MRI scan and Doppler studies. Several studies have evaluated the markers that distinguish between asphyxiated and normal neonates and also to assess the severity of perinatal asphyxia.

In this study, an attempt was made to ascertain the utility of urinary uric acid to creatinine ratio as a biochemical marker of perinatal asphyxia. This study showed a significant increase in the urinary uric acid /creatinine ratio in asphyxiated neonates in comparison to the normal neonates. The results of our study were similar to that of a previous study which reported significantly higher mean urinary uric acid/creatinine ratio in the asphyxiated group when compared to neonates who were not asphyxiated $(2.75 \pm 0.18$ vs $1.78 \pm 0.23, \mathrm{p}<0.0001) .{ }^{[8]}$ In another study, mean urinary $\mathrm{UA} / \mathrm{Cr}$ ratio was $2.58 \pm 1.09$ and $0.86 \pm 0.17$, in asphyxiated group and control group, respectively. ${ }^{[1]}$ Several studies done in other centers also found similar observations. ${ }^{[12-18]}$

Urinary uric acid / creatinine ratio has been found to correlate with different stages of hypoxic ischemic encephalopathy. The ratio was significantly higher in severe HIE (3.61 \pm 0.61$)$ when compared with moderate HIE (2.95 \pm 0.98$)$ and with mild HIE $(2.64 \pm 0.25$, $\mathrm{p}<0.01) .{ }^{[19]}$ As the number of neonates with severe

Table 3. Predictive validity of urinary $\mathrm{UA} / \mathrm{Cr}$ ratio in predicting perinatal asphyxia $(n=76)$.

\begin{tabular}{lccc} 
& & & \multicolumn{2}{c}{$\mathbf{9 5 \%} \mathbf{C l}$} \\
\cline { 2 - 3 } Parameter & Value & Lower & Upper \\
Sensitivity & $92.11 \%$ & $78.62 \%$ & $98.34 \%$ \\
Specificity & $92.11 \%$ & $78.62 \%$ & $98.34 \%$ \\
False positive rate & $7.89 \%$ & $1.66 \%$ & $21.38 \%$ \\
False negative rate & $7.89 \%$ & $1.66 \%$ & $21.38 \%$ \\
Positive predictive value & $92.11 \%$ & $78.62 \%$ & $98.34 \%$ \\
Negative predictive value & $92.11 \%$ & $78.62 \%$ & $98.34 \%$ \\
Diagnostic accuracy & $92.11 \%$ & $83.60 \%$ & $97.05 \%$ \\
Positive likelihood ratio & 11.67 & 3.75 & 34.699 \\
Negative likelihood ratio & 0.09 & 0.01 & 0.255 \\
\hline
\end{tabular}


asphyxia was low in our study, the comparison of the ratio in varying severity of HIE could not be done.

Urinary UA/Cr ratio was useful as a marker of perinatal asphyxia in both term as well as preterm neonates who are asphyxiated. The ratio was significantly higher in asphyxiated preterm neonates in comparison to asphyxiated term neonates. ${ }^{[20]}$ As preterm neonates were excluded in our study, this comparison was not done.

We observed male preponderance $(52.63 \%)$ in the asphyxiated group while in a previous study, female neonates $(52.5 \%)$ were more common. ${ }^{[8]}$ Our study observed that only 6 neonates were of low birth weight of which 4 were in the asphyxiated group. It was also observed that mean birth weight was normal in the asphyxiated group $(2.87 \mathrm{~kg})$ while a previous study found a lower mean birth weight of $2.31 \mathrm{~kg}{ }^{[8]}$ We also observed that mean \pm standard deviation for birth weight $(2.87 \pm 0.36$ vs $2.95 \pm 0.3)$, mean \pm standard deviation for length $(46.61 \pm 1.5$ vs $46.79 \pm 1.28)$ and mean \pm standard deviation for head circumference $(33.58 \pm 0.83$ vs $33.63 \pm 0.79$ ) were similar in both the groups. Although prematurity and intrauterine growth restriction (IUGR) are considered as fetal risk factors for perinatal asphyxia, preterm cases were excluded in our study and IUGR were not observed in the asphyxiated group.

Our study observed that the urinary $\mathrm{UA} / \mathrm{Cr}$ ratio correlated well with the umbilical cord arterial blood gas values and the Apgar scores. We observed a moderate negative correlation between urinary uric acid/ creatinine ratio and 1-minute Apgar score ( $\mathrm{r}=-0.710$, $\mathrm{p}<0.001)$ and also 5-minute Apgar score $(\mathrm{r}=-0.925$, $\mathrm{p}<0.001)$. Observations similar to ours were also made by other studies. ${ }^{[12,17]}$

Our study showed a strong negative correlation with the $\mathrm{pH}$ and moderate negative correlation with $\mathrm{pO}_{2}$ values and a moderate positive correlation with $\mathrm{pCO}_{2}$ values. Similar observations were made by previous studies. ${ }^{[8,18]}$

We found that the urinary $\mathrm{UA} / \mathrm{Cr}$ ratio had excellent predictive value in predicting perinatal asphyxia, as indicated by AUC of 0.943 (95\% CI 0.887 to 0.999 , $\mathrm{p}<0.001)$. Similar observations were made in a previous study in which urinary $\mathrm{UA} / \mathrm{Cr}$ ratio $>2.43$ had $80 \%$ sensitivity, $87.5 \%$ specificity with AUC of 0.84 $(\mathrm{p}=0.003)$ and had a better predictive value. ${ }^{[18]}$ In anoth- er study it was shown that urinary UA/Cr ratio had an accuracy of $80 \%$, sensitivity of $86.6 \%$, a positive predictive value of $82.1 \%$ and a negative predictive value of $78.1 \%$, hence showing that this test allows rapid detection of asphyxia and also can predict short-term outcome as well as long-term outcome. ${ }^{[21]}$ Limitations of our study were that it has small sample size, preterm neonates were not included and there were fewer cases in the category of severe asphyxia.

\section{Conclusion}

Perinatal asphyxia is a common neonatal condition causing morbidity and mortality in developing countries. The signs of this condition are not specific and often have an overlap with other diseases. To support the clinical diagnosis of asphyxia there is need for a cheap non-invasive test as an alternative to arterial blood gas analysis. Utility of urinary uric acid to creatinine ratio as a biochemical marker of perinatal asphyxia was studied and it was found that the ratio correlated well with the umbilical cord arterial blood gas values and the Apgar scores. This study showed a significant increase in the urinary $\mathrm{UA} / \mathrm{Cr}$ ratio in asphyxiated neonates in comparison to the normal neonates.

Funding: This work did not receive any specific grant from funding agencies in the public, commercial, or not-for-profit sectors.

Compliance with Ethical Standards: The authors stated that the standards regarding research and publication ethics, the Personal Data Protection Law and the copyright regulations applicable to intellectual and artistic works are complied with and there is no conflict of interest.

\section{References}

1. Lawn JE, Cousens S, Zupan J; Lancet Neonatal Survival Steering Team. 4 million neonatal deaths: When? Where? Why? Lancet 2005;365(9462):891-900. [PubMed] [CrossRef]

2. National Neonatal-Perinatal Database. Report for the year 2002-03 [Internet]. New Delhi: WHO Collaborating Center for Training and Research in Newborn Care. Department of Pediatrics, All India Institute of Medical Sciences; 2005 [cited Jan 2005]. Available from: http://www. newbornwhocc.org/pdf/nnpd_report_2002-03.pdf

3. Porter KB, O'Brien WF, Benoit R. Comparison of cord purine metabolites to maternal and neonatal variables of hypoxia. Obstet Gynecol 1992;79:394-7. [PubMed] [CrossRef]

4. Palmer C, Vannucci RC, Towfighi J. Reduction of perinatal hypoxic ischemic brain damage with allopurinol. Pediatr Res 1990;27:332-6. [PubMed] [CrossRef] 
5. Poulsen JP, Rognum TO, Oyasaeter S, Saugstag OD. Changes in oxypurine concentration in vitreous humor of pigs during hypoxemia and post-mortem. Pediatr Res 1990;28:482-4. [PubMed] [CrossRef]

6. Swanstrom S, Bratteby LE. Hypoxanthine as a test of perinatal hypoxia as compared to lactate, base deficit and $\mathrm{pH}$. Pediatr Res 1982;16:156-60. [PubMed] [CrossRef]

7. Poulsen JP, Oyasaeter S, Sanderud J, Rognum TO, Saugstad OD. Hypoxanthine, xanthine, and uric acid concentration in the cerebrospinal fluid, plasma, and urine of hypoxemic pigs. Pediatr Res 1990;28:477-81. [PubMed] [CrossRef]

8. Patel KP, Makadia MG, Patel VI, Nilayangode HN, Nimbalkar SM. Urinary uric acid/creatinine ratio - a marker for perinatal asphyxia. J Clin Diagn Res 2017;11:SC08-SC10. [PubMed] [CrossRef]

9. James LS, Weisbrot IM, Prince CE, Holaday DA, Apgar V. The acid-base status of human infants in relation to birth asphyxia and the onset of respiration. J Pediatr 1958;52:37994. [PubMed] [CrossRef]

10. Apgar V. A proposal for a new method of evaluation of the newborn infant. Curr Res Anesth Analg 1953;32:260-7. [PubMed]

11. Krishnana E, Ponnusamy V, Sekar SP. Study of urinary uric acid and creatinine ratio as a marker of neonatal asphyxia for babies born in a tertiary care hospital. Int J Res Med Sci 2017;5: 5418-23. [CrossRef]

12. Sreekrishna Y, Eregowda A, Aarthi Sharma HL. Study of urinary uric acid to creatinine ratio as a biochemical marker of perinatal asphyxia and its correlation with APGAR score. Int J Contemp Pediatrics 2018;5:1485-9. [CrossRef]

13. Basu P, Som S, Choudhari N, Das H. Correlation between APGAR score and urinary uric acid to creatinine ratio as a marker of Perinatal asphyxia. Indian J Clin Biochem 2008;23: 361-4. [PubMed] [CrossRef]

14. Erdag GC, Vitrinel A. Can urinary uric acid and creatinine ratio be used as a additional marker for neonatal asphyxia? International Pediatrics 2004;19:217-9.

15. Akisü M, Kültürsay N. Value of urinary uric acid to creatinine ratio in term infants with perinatal asphyxia. Acta Pediatr Jpn 1998;40:78-81. [PubMed] [CrossRef]

16. Banupriya C, Ratnaker, Doureradjou P, Mondal N, Vishnu B, Koner BC. Can urinary excretion rate of malondialdehyde, uric acid and protein predict the severity and impending death in perinatal asphyxia? Clin Biochem 2008;41:968-73. [PubMed] [CrossRef]

17. Bader D, Gozal D, Wenger-Abend M, Berger A, Lanir A. Neonatal urinary uric acid and creatinine [correction of ceratinine] ratio as a additional marker of perinatal asphyxia. Eur J Pediatr 1995;154:747-9. [PubMed] [CrossRef]

18. Bhongir AV, Yakama AV, Saha S, Radia SB, Pabbati J. The Urinary uric acid to creatinine ratio is an adjuvant marker for perinatal asphyxia. Eur J Pharm Med Res 2015;2:520-8. [PubMed]

19. Choudhary L, Palsania S, Berwal PK, Sauparna CH, Maheshwari A. Study of urinary uric acid and creatinine ratio as a marker of perinatal asphyxia and its correlation with different stages of hypoxic ischemic encephalopathy. J Pregnancy Child Health 2017;4:336. [CrossRef]

20. Chen HJ, Yau KI, Tsai KS. Urinary uric acid and creatinine ratio as an additional marker of perinatal asphyxia. J Formos Med Assoc 2000;99:771-4. [PubMed]

21. El Sayed LM. Urinary uric acid/creatinine ratio and Simkin's index as markers of perinatal asphyxia. Egyptian Journal of Neonatology 2001;2:105-114. 